\title{
OBITUARIES
}

\section{Prof. Alexander Findlay}

Alfixander Findlay died on September 14, aged 92. He was born in the small Kincardineshire town of Johnshaven, and educated at the Grammar School, Aberdeen, where he gained the love of music which was to give him so much pleasure throughout his life. He obtained his M.A. in 1895 and his B.Se. in 1897 at the University of Aberdeen, being awarded special distinction in ehemistry and physiology. F. R. Japp, who was then professor of chemistry, invited Findlay to become his private research assistant, but in 1898, on gaining an 1851 Exhibition Science Scholarship, Findlay went to Leipzig to study physical chemistry under Ostwald; in 1900 he obtained his Ph.D.

When he returned to Britain he accepted an invita. tion from Purdie to join his staff at St. Andrews, but a feeling of isolation after the stir of the laboratories at Leipzig prompted him to move to London to work with Ramsay. In 1902 he obtained his D.Sc. at Aberdeen, and received an appointment at Birmingham on the staff of P. F. Frankland, which proved most fruitful from the research point of view. Under Japp at Aberdeen, Findlay had worked on ketones and some organic condensations, but after his return from Germany his interest was in physical chemistry; the phase rule, colloids, racemates and the solubility of gases.

In 1911 Findlay was appointed professor of chemistry at the University College of Wales, Aberystwyth, and director of the Edward Davies Chemical Laboratories, where new accommodation offered a great challenge. The First World War intervened, however, and he had to devote much time and energy to war work, with occasional visits to France, and later to Germany, on lecture tours. In 1919, Findlay realized one of his great ambitions when he was appointed professor at Aberdeen. Earlier that vear, the University Court, realizing the inadequacy of the existing building, had decided to erect a new building for chemistry, and it was with great hopes for the future that Findlay took up his duties in October 1919. He realized that to build a strong school of research both accommodation and postgraduate students were essential; in 1921 he persuaded his science colleagues to approve regulations for an honours B.Sc. degree and for the Ph.D. degree. Unfortunately, the plans for a new department were foiled by his medical colleagues who were advocating a new Hospital and Medical School. The struggle went on for almost 20 years, until the City of Aberdeen raised the funds necessary for the new Hospital, and the Court, in 1939 , decided that a new chemistry department should be built at Old Aberdeen. In order that his successor could undertake the planning, Findlay resigned, but, before H. W. Melville could take up office, the Second World War began and Findlay agreed to continue in office. In 1943 he was elected president of the Royal Institute of Chemistry; this meant frequent visits to London, and the Court obtained the release of Melville from his war timo duties. In 1944 the University awarded Findlay the degree of LL.D.

Clarity of thought and expression are necessary attributes of the lecturer, and these Findlay possessed in high degree. He was a stimulating teacher. Meticulous in everything he did, he took infinite care in the preparation not only of the lecture but also of the lecture-table experiments. Discipline within his lecture theatre was quietly yet firmly maintained. His accuracy and lucidity of expression are also evident in his many publications; titles include The Phase Rule and its Applications (nine editions), Practical Physical Chemistry (eight editions),
Chemistry in the Service of Man, Osmotic Pressure and The Teaching of Chemistry in the Universities of Aber. deen, a study prompted by his great love of his own University.

Findlay gave much of his time to the advancement of the chemical professional bodies. He served on the council of the Chemical Society and of the Faraday Society and also on the Chemical Council, but it was the Royal Institute of Chemistry that was nearest to his heart and gave him the greatest opportunity to work for the profession to which he had dedicated his life. Even after his retirement from the presidency he devoted himself to the problems associated with the post-war world. He found great pleasure in travel whethor on pleasure, to attend scientific meetings or on behalf of a professional body. It was in the Engadine that he met Alice Mary de Rougement; they were married in 1914 and for more than 50 years she, with their two sons, shared his life. While on a visit to South Africa in 1948 news reached them of his appointment as C.B.E.; the citation, which gave him the greatest of pleasure, so aptly summarizes his life's theme"For service to chemistry". $\quad$ R. B. STRATHDEE

\section{Dr. Pieter Debye}

Pieter Debye, who died on November 2, exerted on chemistry an influence as deep and pervasive as that of any man in this century. He was basically a physicist and was professor of physics in Zürich, Utrecht, Göttingen. Leipzig, and, as Institute director, in Berlin. It was for chemistry, however, that he received the Nobel Prize in 1936, and after he went to Cornell in 1939 he became professor of chemistry.

He was in the great line of Dutch physical chemists, and historically he can be placed alongside van't Hoff. His earlier work on the specific heats of solids at low temperatures was a considerable contribution to physics, but it was later work on the theory of eloctrolytes and on the dielectric properties of chemical substances in relation to their molecular structure that made his name known in every laboratory in the world where there is interest in quantitative chemistry. His work on the technique of $\mathrm{X}$-ray crystal analysis, the application of X-ray analysis to gases and then the major triumph of the electron diffraction method would also in themselves have ensured enduring fame.

The famous Debye-Hückel theory of electrolytes considered the distribution of ions in solution in such a way that each ion could be treated statistically as though it were surrounded by a static cloud or atmosphere of ions of the opposite sign. The idea was amenable to mathematical handling, as well as giving a vivid picture of the behaviour of ions in solution. It completely revolutionized the way most physical chemists looked on electrolytes.

Perhaps the most important of the ideas and methods introduced by Debye was that of the molecular dipole moment and the means of determining it. This constant related structure and electron distribution to properties in the most vivid way, and illuminated general questions of molecular forces and valencies, besides offering approaches to innumerable special probloms of structure and behaviour in chemistry. The peculiar and characteristic combination of subtlety and directness was further evident in his later work on the structure and light scattering of colloidal solutions.

Debye was born in Holland in 1884. He was of robust physique and of genial, friendly and sanguine tempera. ment. He welcomed visitors in his own laboratory and himself enjoyed travelling to laboratories abroad. $\mathrm{He}$ was very interested in the work of others, a fact which, together with his great ability as a lecturer both in German and English, strongly roinforced his influence, if scientific contributions of such power needed reinforcement.
C.N.H. 